Majka Łojko*

\title{
PARTNERSTWO LOKALNE W EKONOMII SPOŁECZNEJ JAKO NOWY PARADYGMAT BUDOWANIA SPÓJNOŚCI SPOŁECZNEJ
}

\section{Wprowadzenie}

Idea partnerstwa lokalnego doskonale wpisuje się w obszar działań sektora ekonomii społecznej. Stanowi rzeczywistą potrzebę, której celem jest skuteczne zaspokajanie potrzeb środowisk lokalnych praktycznie we wszystkich sferach życia społecznego. Występuje wtedy, gdy współdziałanie w wykonywaniu zadań publicznych pomiędzy stronami nie ma charakteru incydentalnego, ale odbywa się w dłuższym czasie i jest powtarzalne, a każda ze stron znajduje się w równorzędnej pozycji, co oznacza zarówno takie same prawa, jak i obowiązki. Powinno to prowadzić do tworzenia podstaw organizacyjnych dla współpracy z administracją publiczną i biznesem w sferze wykonywania działalności społecznie użytecznej i zadań w zakresie pożytku publicznego. Aktualnie jest jedną z ważniejszych sfer praktyki funkcjonowania wielu podmiotów ekonomii społecznej oraz elementem procesu prywatyzacji usług publicznych ${ }^{1}$.

Podjęcie tematu partnerstw lokalnych w kontekście wspierania inicjatyw z zakresu ekonomii społecznej nie jest zabiegiem przypadkowym. Kluczowej roli partnerstw w promowaniu ekonomii społecznej dowiodły doświadczenia ostatnich lat. Można bez wątpienia stwierdzić, że ekonomia społeczna ze względu na złożoność problematyki jest niejako „skazana na partnerstwa”. Podmioty działające w obszarze ekonomii społecznej łączą różne dziedziny i zadania, np. integrację społeczną z aktywizacją zawodową, przedsiębiorczość z przeciwdziałaniem wykluczeniu, rozwój gospodarczy ze zwiększeniem aktywności społecznej mieszkańców. Trudno więc sobie wyobrazić, by tak szeroki wachlarz problemów i zagadnień, wymagający szczególnych kompetencji

Wydział Nauk Społecznych, Uniwersytet Warmińsko-Mazurski w Olsztynie.

1 M. Baron-Wieczorek, I. Grzanka, Partnerstwo społeczno-publiczne we wspólnotach terytorialnych, „Zeszyty Naukowe Politechniki Śląskiej” nr 76, 2014, s. 218. 
i zasobów, został objęty działaniem wyłącznie jednego podmiotu, z pominięciem partnerskiej współpracy².

Głównym celem artykułu jest określenie partnerstwa lokalnego w ekonomii społecznej jako nowego paradygmatu budowania spójności społecznej. Zasadnicza teza artykułu zawiera się w stwierdzeniu, że rozwój przedsiębiorczości społecznej zależy przede wszystkim od partnerskiego jej współdziałania z kluczowymi partnerami - administracją publiczną i biznesem.

\section{Istota partnerstw lokalnych w praktyce ekonomii społecznej}

Ekonomia społeczna odwołuje się do szerokiego kontekstu społeczno-gospodarczego, w którym wzbudzenie nowych relacji, pojawienie się nowych produktów czy też tworzenie nowych instytucji powoduje, że wzmacnia się poczucie wspólnoty lokalnej i wzrasta poziom integracji społecznej. Jednak dla swojego urzeczywistnienia wymaga aktywności społecznej i zakorzenienia w lokalnych warunkach, jak również oparcia jej na lokalnym partnerstwie.

Sama idea partnerstwa lokalnego powstała już około 1980 r. w Kanadzie, skąd pomysł dotarł do Stanów Zjednoczonych, gdzie wykorzystano go przy procesie likwidacji ówczesnych nierentownych hut i kopalni. Ponieważ efekty podjętych działań przyniosły pozytywne skutki, stworzono tzw. model partnerstwa lokalnego, który następnie został rozpowszechniony na całym świecie. Te modelowe rozwiązania zaczęto stosować w innych krajach, głównie w krajach anglosaskich. Wprawdzie na początku inicjatywy partnerskie miały formę partnerstw publiczno-prywatnych jak również partnerstw między biznesem a instytucjami publicznymi, powoływanymi, by rozwiązać konkretny problem w środowisku, o krótkoterminowym charakterze. Z czasem dostrzeżono w partnerstwach, ich doświadczeniu i wiedzy szansę na rozwiązywanie ważnych problemów społecznych ${ }^{3}$.

Na przełomie XX i XXI w. Unia Europejska doceniła olbrzymi potencjał i możliwości, jakie niesie ze sobą partnerstwo lokalne, którego zasada stała się jedną z kluczowych reguł obowiązujących przy realizacji inicjatyw prorozwojowych wspieranych ze środków $\mathrm{UE}^{4}$. Ten rodzaj partnerstwa jest zdaniem R. Lukescha swoistego rodzaju

2 M. Lewandowska, Droga do partnerstwa - kilka ważnych pytań, FISE, Warszawa 2013, s. 4.

3 Przez wspólprace do sukcesu. Partnerstwo lokalne na rynku pracy, red. A. Sobolewski, Departament Rynku Pracy, Warszawa 2007, s. 9-10.

4 Ibidem, s. 9. 
koncepcją przymierza partnerów powiązanych wspólnymi dążeniami, objętego akceptowanymi regułami, jest też najlepszym spoiwem oddolnego charakteru uczestnictwa podmiotów lokalnych z odgórnym, zdecentralizowanym wsparciem i finansowaniem podejmowanych programów. Dzięki tego typu współpracy wzmocnieniu ulega koordynacja działań lokalnych, kooperacja oraz sama aktywność społeczna ${ }^{5}$, a kluczowe jest dobro wspólne traktowane jako fundament każdego partnerstwa, łączy bowiem partnerów, pomimo czasem występujących rozbieżności i sprzeczności interesów. Cechą charakterystyczną partnerstwa jest więc integracja, jedność i spójność działań partnerów ${ }^{6}$. R. Tennyson i L. Wilde mianem partnerstwa określają międzysektorowe alianse, $\mathrm{w}$ ramach których jednostki, grupy i organizacje reprezentujące różne sektory zgadzają się współpracować po to, aby wypełnić zobowiązanie lub podjąć specyficzne zadanie, wnosząc swoje kompetencje i zasoby, wspólnie ponosząc ryzyko i koszty, równocześnie dzieląc się korzyściami wynikającymi z osiągnięcia wspólnych celów partnerstwa i poszczególnych organizacji członkowskich ${ }^{7}$.

Partnerstwa lokalne nie są w Polsce zjawiskiem nowym, istnieją już od lat 90. ubiegłego wieku. W tym czasie Polska przystąpiła do wdrażania i realizacji modelu partnerstwa lokalnego, zaś w 2002 r. Departament Pracy USA oraz polskie Ministerstwo Pracy i Polityki Społecznej oficjalnie zainaugurowały działalność tego modelu8. Współpraca pomiędzy administracją publiczną a trzecim sektorem została prawnie usankcjonowana w Ustawie z dnia 24 kwietnia 2003 r. o działalności pożytku publicznego i o wolontariacie, która szczegółowo unormowała zasady współpracy administracji publicznej z organizacjami pozarządowymi, określając jej formy, sposób zlecania oraz wsparcia zadań publicznych. Art. 5 wskazuje, że „[...] organy administracji publicznej prowadzą działalność w sferze zadań publicznych [...] we współpracy z organizacjami pozarządowymi [...]. Współpraca [...] odbywa się na zasadach: pomocniczości, suwerenności stron, partnerstwa, efektywności, uczciwej konkurencji i jawności”.

Idea partnerstwa, mimo długoletniej przynależności Polski do Unii Europejskiej, silnie promującej tego typu działania, nadal wzbudza żywe zainteresowanie zarówno

5 R. Lukesch, The LAG - handbook. A guide through the stunning world of local actions groups, LEANDER+ OBSERVATORY CONTACT POINT, Brussels 2007, s. 3.

6 B. Hudson, M. Exworthy, S. Peckham, The Integration of Localised and Collaborative Purchasing: a Review of the Literature and Framework for Analysis, Nuffield Institute for Health, University of Leeds, University of Southampton 1998, s. 8.

7 R. Tennyson, L. Wilde, The guiding hand. Brokering partnerships for sutainable development, United Nations Department of Public Information, New York 2000, s. 12.

8 W Polsce funkcjonuje kilka modeli partnerstw, obok wskazanego modelu, a także m.in. lokalne grupy działania (LGD) funkcjonujące w ramach Programu Leader Plus (Leader+) czy też klastry (zwane także gronami, z ang. cluster - grono) skupiające grupy instytucji i organizacji związanych określoną branżą i działające na określonym obszarze. 
z teoretycznego, jak i praktycznego punktu widzenia. Wzrost jej popularności jest niewątpliwie efektem „unijnej konieczności”, ale też ewolucyjnej zmiany podejścia do zarządzania w polskich jednostkach samorządu terytorialnego - od nowego publicznego zarządzania (New Public Management) do governance ${ }^{9}$.

Jak dotąd, samo pojęcie partnerstwa nie zostało ściśle zdefiniowane w sensie formalnym, niemniej jednak zdaniem J. Wygnańskiego w przestrzeni publicznej funkcjonuje swoistego rodzaju intelektualna figura, stworzona w celu podkreślenia jego odrębności i zaakcentowania istotnego składnika tego rodzaju przedsięwzięć, jakim jest udział strony społecznej rozumianej jako społeczność lokalna ${ }^{10}$. Określane jest najczęściej jako „platforma współpracy pomiędzy różnorodnymi partnerami, którzy wspólnie w sposób systematyczny, trwały z wykorzystaniem innowacyjnych metod oraz środków planują, projektują, wdrażają i realizują określone działania i inicjatywy, których celem jest rozwój lokalnego środowiska społeczno-gospodarczego i budowa tożsamości lokalnej wśród członków danej społeczności”"11.

Partnerstwo jest też często ujmowane jako dynamiczna relacja pomiędzy różnymi podmiotami, oparta na wspólnie uzgodnionych celach, urzeczywistnianych dzięki ogólnie przyjętemu rozumieniu najbardziej racjonalnego podziału pracy z uwzględnieniem przewagi komparatywnej każdego partnera. W tym rozumieniu obejmuje wzajemne oddziaływanie, przy starannym zachowaniu równowagi pomiędzy zbliżeniem a autonomią, na którą składa się wzajemny szacunek, równy udział w procesie decyzyjnym, wzajemna odpowiedzialność i przejrzystość ${ }^{12}$. Jego istota polega przede wszystkim na podejmowaniu zintegrowanych działań przez instytucje, organizacje i osoby $\mathrm{z}$ różnych środowisk oraz sektorów i wymaga podejmowania wspólnych decyzji, działań, odpowiedzialności i wkładu każdego z partnerów. Współpraca w ramach partnerstwa obejmuje praktycznie wszystkie aspekty życia społecznego i gospodarczego - od polityki zatrudnienia i rynku pracy, przez pomoc społeczną, edukację, aż po szeroko rozumianą przedsiębiorczość. Jeśli współpraca jest prawidłowo realizowana i rozumiana przez wszystkich partnerów, z czasem może przyczynić się do osiągnięcia tzw. efektu synergii ${ }^{13}$.

9 M. Kalisiak-Mędelska, Partnerstwo lokalne - istota i znaczenie na przykładzie lokalnych grup działania, „Biblioteka Regionalisty” nr 13, 2013, s. 73.

10 J. Wygnański, Skuteczne animowanie kultury współpracy - czynniki sukcesu w procesie budowy partnerstw, [w:] Partnerstwo - wspótpraca międzysektorowa w realizacji celów społecznych, red. A. Handzlik J. Głowacki, Małopolska Szkoła Administracji Publicznej, Uniwersytet Ekonomiczny w Krakowie, Kraków 2014, s. 10.

11 Przez wspótprace do sukcesu..., op.cit., s. 10.

12 J.M. Brinkerhoff, Government-Nonprofit partnership: A defining framework, „Public Administration and Development" Vol. 22, 2002, s. 19-30.

13 T. Kozłowski, Partnerskie pryncypia, [w:] Partnerstwo społeczne - model rozwoju Polski, red. W. Misztal, A. Zybała, Centrum Partnerstwa Społecznego DIALOG, Warszawa 2008, s. 164-165. 
Według T. Schimanek partnerstwa są forum generowania i realizacji innowacyjnych pomysłów. Mogą też być źródłem kreowania nowych rozwiązań wyzwalanych w wyniku budowania nieformalnych sieci powiązań. Ponadto wzmacniają więzi pomiędzy administracją samorządową i organizacjami społecznymi ${ }^{14}$. Ich tworzenie powinno się rozpoczynać od animowania społeczności lokalnej i odbudowywania zaufania, więzi społecznych i wspólnot. Mogą być mniej lub bardziej sformalizowane, nie mniej jednak muszą stanowić realne, społeczno-instytucjonalne zaplecze zarówno dla nowych, jak i funkcjonujących już podmiotów ekonomii społecznej. Przedsiębiorstwo społeczne powinno bowiem „wyrastać z możliwie szerokiego partnerstwa lokalnego (lub wspólnoty lokalnej). Tylko wtedy może trafnie zidentyfikować dla siebie niszę rynkową, nie zaburzając mechanizmów konkurencyjności na lokalnym rynku (zwłaszcza na etapie wykorzystywania środków publicznych)”. Z kolei społeczność lokalna powinna być postrzegana jako podmiot ekonomii społecznej, który może wykorzystywać instrumenty ekonomiczne i społeczne w celu podnoszenia jakości życia wszystkich jej mieszkańców ${ }^{15}$.

\section{Rodzaje partnerstw}

Zgodnie z raportem OECD partnerstwa stanowią system sformalizowanej współpracy pomiędzy kilkoma instytucjami opartej na prawnie zawartej umowie lub porozumieniu nieformalnym, powiązaniach w ramach działań kooperacyjnych i wspólnie przyjętych planach. Raport dzieli partnerstwa na publiczne i publiczno-prywatne. Pierwsze z nich obejmują m.in. porozumienia pomiędzy reprezentantami różnych poziomów władzy administracyjnej, drugie zaś porozumienia pomiędzy podmiotami publicznymi i prywatnymi, przy czym do podmiotów prywatnych autorzy raportu zaliczają zarówno przedsiębiorstwa, jak i wszelkie organizacje pozarządowe ${ }^{16}$.

Najbardziej przejrzysta i niebudząca wątpliwości typologia partnerstw oparta jest o trzy podstawowe sektory działalności społeczno-gospodarczej: społeczny, publiczny, prywatny. Uznając zatem partnerstwo za przejaw współpracy pomiędzy różnymi typami sektorów, należy przyjąć, że może ono występować w następujących czterech podstawowych formach.

14 T. Schimanek, E jak EQUAL. P jak Partnerstwo, Instytut Spraw Publicznych, Warszawa 2007, s. 24.

15 A. Juros, A. Biały, Partnerstwo w praktyce przedsiębiorstw ekonomii społecznej. Dobre praktyki, Lubelska Spółdzielnia Socjalna Koziołek, Lublin 2011, s. 125.

16 Local Partnership for Rural Development, OECD, Paris 1990, s. 18. 
Partnerstwo publiczno-prywatne $\mathbf{1}^{17}$ (public-private partnership) są to umowy zawarte na czas określony pomiędzy partnerem instytucji publicznej a partnerem prywatnym w celu zrealizowania określonego przedsięwzięcia gospodarczego. $\mathrm{Na}$ tej podstawie partner prywatny finansuje utworzenie infrastruktury potrzebnej do świadczenia usługi publicznej, a następnie pobiera opłatę za świadczenie tej usługi. Warto wskazać, że partnerstwo publiczno-prywatne (PPP) nie może być traktowane jako partnerstwo na rzecz społecznej odpowiedzialności biznesu, ponieważ CSR nie jest narzędziem polityki. PPP umożliwiają zwalczanie i eliminowanie problemów społecznych poprzez integrację działań prywatnych i publicznych i stanowią narzędzia polityki (sektor publiczny - biznes).

Partnerstwo publiczno-społeczne (public-social partnership) stanowi podstawę rozwoju usług społecznych. Dotyczy współpracy gminy lub powiatu z organizacjami pozarządowymi w celu kontraktowania, zlecania i realizacji zadań w obszarach pożytku publicznego. Często są to usługi związane z rynkiem pracy oraz pomocą społeczną. W tym kontekście tego rodzaju partnerstwa nie mogą być rozważane jako narzędzie CSR. Są bowiem narzędziami służącymi do realizacji pewnych założeń, polityk i zadań sektora publicznego (przedstawiciele społeczności lokalnej, sektor publiczny - organizacje pozarządowe).

Partnerstwo społeczno-prywatne (public-private partnership) to dobrowolna współpraca przedstawicielstw instytucji publicznych i pozarządowych, której celem jest wspólne osiąganie zamierzeń, dokonywanie wzajemnej wymiany zasobów i doświadczeń. Zawierane jest najczęściej w celu rozwiązywania konkretnych problemów społecznych, środowiskowych, zdrowia, edukacji, lokalnych lub innych (sektor pozarządowy - biznes).

Partnerstwo międzysektorowe (cross-sector partnership) składa się z przedstawicieli wszystkich trzech sektorów. Są to zwykle duże partnerstwa zawierane w celu realizacji regionalnych, ogólnokrajowych czy też międzynarodowych projektów ${ }^{18}$.

Każdy z wymienionych rodzajów partnerstwa wyróżniają szczególne cechy, które tworzą podstawę jego działania. Niemniej jednak poszczególne ich rodzaje wzajemnie nie wykluczają się, gdyż stanowią swoiste uzupełnienie wszelkich podejmowanych działań.

Zdaniem B. Kotarby dokonanie jednoznacznych podziałów i przyporządkowywanie konkretnych partnerstw wyłącznie do jednego z wymienionych typów jest raczej

17 Szczegółowego opracowania prawnego doczekała się jedynie ta forma partnerstwa, przybierając kształt Ustawy z dnia 19 grudnia 2008 r. o partnerstwie publiczno-prywatnym, DzU 2009, nr 19, poz. 100. $\mathrm{W}$ art. 1.1 ustawa określa zasady współpracy podmiotu publicznego i partnera prywatnego w ramach partnerstwa publiczno-prywatnego.

18 http://wiadomosci.ox.pl/wiadomosc,25024, partnerstwo-na-rzecz-ekonomii-.html [dostęp 3.01.2018]. 
niemożliwe. W zależności od cech, jakimi charakteryzują się poszczególne rodzaje partnerstw, można przyporządkować je jednocześnie do kilku typów. Jest to zaleta typologii, które są niewyczerpujące i rozłączne, dzięki czemu ułatwiają wielowymiarowe, a konsekwencji bardziej wnikliwe analizy ${ }^{19}$.

O ile założenia teoretyczne na temat partnerstw i korzyści, jakie można dzięki nim osiągnąć, są oczywiste, to w praktyce nie jest to takie proste. Doświadczenia struktur powstałych w krajach zachodnich pokazują, że stworzenie stabilnego i skutecznego partnerstwa oraz osiągnięcie widocznych efektów w sferze integracji społecznej i zawodowej wymaga co najmniej 10 lat. A. Juros i A. Biały zwracają uwagę na następujące korzyści płynące z zawiązywania tego typu struktur:

- wyzwalanie aktywności mieszkańców społeczności lokalnej,

- łączenie i uzupełnianie się potencjałów, zasobów, wiedzy i umiejętności partnerów oraz wykorzystanie ich do osiągania wspólnych, zintegrowanych celów,

- poprawa skuteczności i efektywności wspólnie realizowanych działań,

- partnerstwa mogą być źródłem kreowania nowych rozwiązań wyzwalanych w wyniku budowania nieformalnych sieci powiązańn ${ }^{20}$.

W dalszych rozważaniach nad partnerską aktywnością sektora ekonomii społecznej na szczególną uwagę zasługuje analiza świadczenia usług zarówno w formule partnerstwa publiczno-społecznego, społeczno-prywatnego, jak i międzysektorowego.

\section{Partnerstwo publiczno-społeczne}

Ekonomia społeczna stanowi jeden z elementów budowania lokalnej polityki publicznej. Często określana jest jako dziedzina aktywności społecznej, nie przynależy ani do państwa, ani też do wolnego rynku. Jej instytucjonalne ramy odpowiadają granicom szeroko rozumianego sektora organizacji pozarządowych. Stąd też z uwagi na specyficzny sposób działania jej podmiotów, przejawiający się m.in. w działalności nienastawionej na osiąganie zysku oraz korzystanie ze świadczeń wolontariuszy, współpraca organów administracji publicznej z organizacjami pozarządowymi określana jest mianem partnerstwa publiczno-społecznego ${ }^{21}$, którego

19 B. Kotarba, Zasady partnerstwa w wybranych działaniach samorządów gminnych, [w:] Partnerstwo w sferze publicznej, red. A. Kołomycew, B. Kotarba, Scholar, Warszawa 2014, s. 112.

20 A. Juros, A. Biały, op.cit., s. 20.

21 J. Ruszewski, Współpraca sektora administracji publicznej i sektora ekonomii społecznej, [w:] Ekonomia społeczna w teorii i praktyce, red. A. Grzybowska, J. Ruszewski, Centrum Aktywności Społecznej PRYZMAT, Suwałki 2010, s. 81 . 
idea w Polsce wyłoniła się po 2002 r. jako alternatywa wobec technokratycznych programów relacji instytucjonalnych. Poprzez strategię kooperacji i wzajemnego wspierania różnych sektorów z obszarów polityki społecznej stanowi przeciwwagę dla nadmiernego urynkowienia usług społecznych ${ }^{22}$. Jest kwintesencją konstytucyjnej zasady pomocniczości, w myśl reguły: „tyle państwa, ile to konieczne, a zarazem tak mało jak to tylko możliwe”. Szczególnego znaczenia tej zasadzie nadaje stwierdzenie, iż władze publiczne powinny koncentrować się na tych zadaniach, których nie można przekazać innym podmiotom i które powinny być wypełniane przez sektor publiczny w imię najszerzej rozumianego interesu publicznego. Zasada ta wskazuje na specyficzny „podział pracy” między poszczególnymi wspólnotami. Oznacza ona, że zawsze wtedy, kiedy mniejsza (lokalna/oddolna) wspólnota jest w stanie podołać rozwiązywaniu danego problemu, tam wspólnota (instytucja) znajdująca się „wyżej” w hierarchii może i powinna wspierać ową wspólnotę w jej wysiłkach, ale nie powinna własnymi działaniami wkraczać na jej terytorium i tym samym wyręczać jej obywateli ${ }^{23}$. Ch. Roffiaen uważa, że zasada pomocniczość opiera się na współdziałaniu i komplementarności obywateli i instytucji publicznych, zaś jej celem jest usprawnienie i ulepszenie dobra publicznego, a nie tylko przeniesienie działalności z sektora publicznego do sektora prywatnego (społecznego) ${ }^{24}$.

W tym kontekście niezbędne jest nadanie odpowiedniego znaczenia inicjatywom obywatelskim, z udziałem sektora ekonomii społecznej, poprzez tworzenie warunków do rozwoju instytucji społeczeństwa obywatelskiego, dialogu obywatelskiego, postaw obywatelskich kształtujących różnorodne formy partycypacji społecznej, a tym samym przyczynienie się do dynamicznego rozwoju koncepcji uspołecznionej formuły usług społecznych ${ }^{25}$.

Partnerstwo publiczno-społeczne zostało formalnie wprowadzone na podstawie ustawy o działalności pożytku publicznego i wolontariacie ${ }^{26}$, traktując je jako nowy mechanizm współpracy różnych podmiotów w realizacji lokalnej polityki społecznej. W świetle ustawy „działalnością pożytku publicznego jest działalność społecznie użyteczna, prowadzona przez organizacje pozarządowe w sferze zadań

22 M. Tkaczuk, Partnerstwo publiczno-społeczne jako etap ewolucji podmiotów polityki społecznej w Polsce, „Annales Universitatis Mariae Curie-Skłodowska”, Sectio H Oeconomia 42, 2008, s. 325.

23 J. Wygnański, Skuteczne animowanie kultury współpracy, [w:] Partnerstwo - współpraca międzysektorowa $w$ realizacji celów społecznych, red. A. Handzlik, K. Głowacki, Małopolska Szkoła Administracji Publicznej, Uniwersytet Ekonomiczny w Krakowie, Kraków 2012, s. 9.

24 Ch. Roffiaen, Rethinking the principle of subsidiarity, „Brussels Report” 2003, s. 7.

25 Projekt „Potencjał - Działanie - Rozwój: nowy wymiar wspótpracy Miasta Płocka i płockich organizacji pozarzadowych", Procedura tworzenie partnerstwa publiczno-społecznego na prowadzenie Centrum Organizacji Pozarządowych i Inicjatyw Obywatelskich Gmina - Miasto Płock, Płock 2014, s. 3.

26 Ustawa z dnia 24 kwietnia 2003 r. o działalności pożytku publicznego i wolontariacie, DzU nr 96, poz. $873 \mathrm{z}$ późn. zm. 
publicznych określonych w ustawie" 27 . W uzasadnieniu włączonym do nowelizacji ustawy wskazano, że „partnerstwo może powstać z inicjatywy jednostki samorządu terytorialnego (gminy lub powiatu) oraz organizacji pozarządowej lub podmiotów, o których mowa w art. 3 ust. 3, posiadających osobowość prawną, jak również spółdzielni socjalnej"28.

Wprowadzenie ustawy było bezpośrednio wynikiem polityki, której założenia zawarto w przyjętym 9 października 2006 r. przez Radę Ministrów Krajowym Programie Zabezpieczenie Społeczne i Integracja Społeczna na lata 2006-2008 ${ }^{29}$. Podkreślono w nim, że „partnerstwo publiczno-społeczne zawiązywane będzie na czas wykonania wspólnego zadania, uzyska w tym czasie status osoby prawnej nienastawionej na zysk. Instytucja partnerstwa publiczno-społecznego będzie wprowadzana przede wszystkim w związku z realizacją lokalnych projektów lub projektów aktywności lokalnej w zakresie zatrudnienia i integracji społecznej”.

Modelowa współpraca administracji publicznej z organizacjami pozarządowymi zgodnie $\mathrm{z}$ art. 5 ustawy o działalności pożytku publicznego i wolontariacie powinna odbywać się na następujących zasadach:

- pomocniczości przy suwerenności stron; organy administracji publicznej, respektując odrębność i suwerenność zorganizowanych wspólnot obywateli, uznają ich prawo do samodzielnego definiowania i rozwiązywania problemów, w tym należących także do sfery zadań publicznych i w takim zakresie współpracują z tymi organizacjami, a także wspierają ich działalność oraz umożliwiają realizację zadań publicznych na zasadach i w formie określonej w ustawie;

- partnerstwa; organizacje pozarządowe, na zasadach i w formie określonej w ustawie oraz według trybu wynikającego z odrębnych przepisów, uczestniczą w identyfikowaniu i definiowaniu problemów społecznych, wypracowywaniu sposobów ich rozwiązania oraz wykonywaniu zadań publicznych;

- efektywności; organy administracji publicznej, przy zlecaniu organizacjom pozarządowym zadań publicznych, dokonują wyboru najefektywniejszego sposobu wykorzystania środków publicznych, przestrzegając zasad uczciwej konkurencji;

- jawności; organy administracji publicznej udostępniają współpracującym z nimi organizacjom pozarządowym informacje o zamiarach, celach i środkach przeznaczonych na realizację zadań publicznych, w których możliwa jest współpraca $\mathrm{z}$ tymi organizacjami oraz o kosztach realizacji zadań publicznych już

27 Ibidem, art. 3.

28 Z. Wejcman, Dialog i partnerstwo a ekonomia społeczna, „Ekonomia Społeczna. Teksty” nr 9, 2007, s. 6.

29 Krajowy Program Zabezpieczenie Społeczne i Integracja Społeczna na lata 2006-2008, MPiPS, Warszawa 2006. 
prowadzonych w tym zakresie przez jednostki podległe organom administracji publicznej lub nadzorowane przez te organy ${ }^{30}$.

Z uwagi na swoją specyfikę partnerstwo publiczno-społeczne może budzić pewne zastrzeżenia związane m.in. ze stosowaniem wspomnianej zasady pomocniczości, która powinna prowadzić raczej do redukowania obszaru działań administracji publicznej, a nie do ich podzlecania organizacjom społecznym. Ponadto pojawia się rozbieżność między tym, kto wykonuje zadanie publiczne (np. organizacja społeczna), a tym, kto ponosi za nie odpowiedzialność (np. wobec społeczeństwa) i ogniskuje na sobie ewentualne niezadowolenie ludności za opieszałość, niską jakość itp. (strona publiczna). Nie sposób też uniknąć groźby ruchów pozornych ze strony administracji publicznej, która bez przekonania będzie urzeczywistniać idee pomocniczości horyzontalnej ${ }^{31}$.

Należy podkreślić, iż instytucja partnerstwa publiczno-społecznego nie stanowi jedynej i wyłącznej możliwości podejmowania współpracy sektora pozarządowego i publicznego. Współpraca ta może być również prowadzona na podstawie umów o wykonywanie inicjatywy lokalnej stanowiących formułę mniej sformalizowaną. W uzasadnieniu do projektu ustawy o zmianie ustawy o działalności pożytku publicznego i o wolontariacie proponuje się koncepcję inicjatywy lokalnej jako nowej formy współpracy, która służyć ma pobudzeniu organizacji obywateli w celu wspólnego rozwiązywania ważnych spraw społeczności lokalnych. Środkiem do osiągnięcia tego celu są umowy zawierane między reprezentantami danej społeczności a władzami gminy służące realizacji postulatów lub ich części określonych we wniosku o realizację inicjatywy.

\section{Partnerstwo społeczno-prywatne}

Ten rodzaj partnerstwa stanowi ważną formę współpracy sektora prywatnego i publicznego. W jego skład wchodzą podmioty prywatne, takie jak przedsiębiorstwa prywatne lub/i fundacje korporacyjne, instytucje otoczenia biznesowego, organizacje

\footnotetext{
30 A. Jabłońska, M. Drażba, Partnerstwo publiczno-społeczne jako „przystępna” forma partnerstwa międzysektorowego, [w:] Partnerstwo międzysektorowe. Możliwości, zasady, realizacja, red. M. Perkowski, Wydawnictwo Prawo i Partnerstwo, Białystok 2009, s. 41-42, [za:] Zasady tworzenia programu wspótpracy jednostek samorzadu terytorialnego $z$ organizacjami pozarzadowymi oraz z podmiotami, o których mowa $w$ art. 3 ust. 3 Ustawy z dnia 24 kwietnia 2003 r. o działalności pożytku publicznego i o wolontariacie, Ministerstwo Gospodarki, Pracy i Polityki Społecznej, Warszawa 2004, s. 5.

31 M. Tkaczuk, op.cit., s. 328.
} 
otoczenia biznesowego oraz podmioty społeczne, czyli przedsiębiorstwa ekonomii społecznej, organizacje pozarządowe, jak również organizacje pożytku publicznego.

$\mathrm{Z}$ uwagi na fakt, że oba sektory funkcjonują na zupełnie odrębnych biegunach, budowanie i funkcjonowanie partnerstw prywatno-społecznych jest często trudnym, czaso- i zasobochłonnym wyzwaniem. Podczas gdy sektor prywatny koncentruje się na maksymalizacji zysku i wartości dla akcjonariuszy, sektor społeczny zajmuje się rozwiązywaniem problemów, z którymi mechanizmy rynkowe sobie nie radzą. U podstaw idei zawiązywania tego rodzaju partnerstw leży przekonanie, że skuteczne rozwiązywanie lokalnych problemów możliwe jest jedynie dzięki zintegrowanej współpracy różnych instytucji. Tworzone partnerstwa służą przede wszystkim aktywizacji społecznej i zawodowej osób zagrożonych marginalizacją i wykluczeniem społecznym przy wykorzystaniu narzędzi rynkowych i potencjału społecznej odpowiedzialności biznesu. Promocja takich rozwiązań to jednocześnie promocja najlepszych praktyk społecznej odpowiedzialności biznesu. Dzięki zawiązywaniu partnerstw społeczno-prywatnych podmioty ekonomii społecznej prowadzące działalność gospodarczą uzyskują realne szanse stania się samofinansującymi się przedsięwzięciami społecznymi, ponadto uzyskują pełną profesjonalizację. To również przejaw realnej odpowiedzialności biznesu, który traktuje swoje zasoby, ludzkie i materialne, jako narzędzia mogące w rzeczywisty sposób przyczynić się do poprawy sytuacji osób zagrożonych marginalizacją i wykluczeniem społecznym. U podstaw jego idei leży założenie, że skuteczne rozwiązywanie lokalnych problemów możliwe jest tylko w toku współpracy różnych instytucji, zgodnie z dewizą „razem można więcej”. Promocja takich rozwiązań jest jednocześnie promocją najlepszych praktyk społecznej odpowiedzialności biznesu.

Niemniej jednak czynnikiem utrudniającym partnerską współpracę są dotychczasowe przyzwyczajenia obu sektorów. Przez lata funkcjonowały one w opozycji do siebie, a biznes był postrzegany przez społeczeństwo i jego organizacje jako przyczyna wielu społecznych, ekologicznych i gospodarczych problemów. Wprawdzie oba sektory podejmowały wspólne projekty w obszarach społecznej odpowiedzialności biznesu, niemniej jednak często raczej szukały możliwości wpływu na siebie nawzajem i uzyskania wymiernych indywidualnych korzyści niż faktycznego rozwiązania dla konkretnego problemu społecznego. Współczesna rzeczywistość wymaga od nich zmian postawy ukierunkowanych na zawieranie partnerstw pozwalających osiągać wspólne cele społeczne przy jednoczesnym zachowaniu indywidualności, wartości i tożsamości każdej ze stron ${ }^{32}$.

32 J. Woźniczka, Partnerstwo jako narzędzie społecznej odpowiedzialności biznesu, http://odpowiedzialnybiznes.pl/artykuly/partnerstwo-jako-narzadzie-spolecznej odpowiedzialnosci-biznesu/ [dostęp 22.01.2018]. 
Jak zauważa K. Wyszkowski, przedstawiciele podmiotów ekonomii społecznej nie powinni traktować biznesu jako jedynie źródła potencjalnych dotacji finansowych. Także sektor prywatny powinien oduczyć się patrzenia na organizacje społeczne jako partnera jedynie w kwestiach podbudowywania swego wizerunku ${ }^{33}$.

\section{Partnerstwo międzysektorowe}

Jednym z praktycznych sposobów wspierania rozwoju regionalnego i lokalnego jest tworzenie partnerstw międzysektorowych określanych jako instytucjonalne formy współpracy podmiotów z różnych sektorów gospodarki - publicznego, prywatnego i pozarządowego. Wzrost popularności i wspieranie tego typu współdziałania jest odzwierciedleniem ogólnej zmiany podejścia do systemu władzy i zarządzania zasobami lokalnymi od hierarchicznego, odgórnego i redystrybucyjnego, do polityki promowania strategii rozwoju opartych na działaniach i procesach oddolnych oraz strukturach „sieciowych” zwiększających udział decyzji podejmowanych kolektywnie z udziałem społeczności lokalnych ${ }^{34}$.

Podstawę współpracy międzysektorowej w Polsce określają między innymi następujące ustawy:

- o działalności pożytku publicznego i o wolontariacie, która umożliwia podejmowanie współpracy administracji i organizacji pozarządowych oraz partnerską realizację zadań na rzecz społeczności lokalnej w formie inicjatywy lokalnej;

- o promocji zatrudnienia i instytucjach rynku pracy, definiująca partnerstwo lokalne jako instytucję rynku pracy, uczestniczącą w procesie realizacji polityki rynku pracy we współpracy z władzami publicznymi; ustawa ta daje też podstawę do wsparcia finansowego partnerstw lokalnych;

- o zasadach prowadzenia polityki rozwoju, która wprowadza pojęcie projektu partnerskiego oraz określa możliwość realizacji w ramach partnerstwa projektów finansowanych ze środków europejskich;

- o partnerstwie publiczno-prywatnym, określająca zasady współpracy podmiotu publicznego i partnera prywatnego w ramach wspólnej realizacji przedsięwzięcia

$33 \mathrm{http} / / /$ www.portalsamorzadowy.pl/polityka-i-spoleczenstwo/cenne-partnerstwo-takze-spoleczno prywatne,20950.html [dostęp 2.02.2018].

34 M. Furmankiewicz, Wspótpraca międzysektorowa w ramach „partnerstw terytorialnych" na obszarach wiejskich w Polsce, „Studia Regionalne i Lokalne” nr 2(24), 2006, s. 117. 
opartej na podziale zadań i ryzyka pomiędzy podmiotem publicznym i partnerem prywatnym ${ }^{35}$.

Zdaniem M. Kaliszewskiej ekonomia społeczna stwarza nowe perspektywy dla grup defaworyzowanych i doświadczających marginalizacji w większości korzystających z usług pomocy społecznej, od której stają się z czasem zależne, co w konsekwencji prowadzi do powielania wzorców wśród następnych generacji, wyzwalając tym samym mechanizm dziedziczenia biedy i ekskluzji społecznej. Dlatego też pula problemów, z którymi usiłuje się zmierzyć ekonomia społeczna - od integracji i rehabilitacji społecznej oraz zawodowej osób zagrożonych wykluczeniem zawodowym i społecznym, poprzez m.in. wzmacnianie spójności społecznej, ekologiczne formy produkcji, po odpowiedzialność konsumencką, odnajduje efektywne rozwiązanie, dzięki zawiązywaniu partnerstw międzysektorowych z sektorem biznesowym oraz $\mathrm{z}$ administracją publiczną ${ }^{36}$.

Bez wątpienia partnerstwa międzysektorowe są formą współpracy, która najlepiej wpisuje się w założenia koncepcji governance, ponieważ ich celem jest instytucjonalizacja (niekoniecznie formalizacja) współpracy nawiązanej z uwagi na zbliżone potrzeby i oczekiwania społeczności. Governance określane jest jako współrządzenie, współzarządzanie czy też system oparty na elastycznych powiązaniach struktur publicznych i pozapaństwowych i nieformalnych, organizowanych dla osiągnięcia określonego celu; zakłada, że rozwiązanie problemów zbiorowych (publicznych) wymaga współpracy zarówno władz i administracji publicznej, obywateli, jak i przedsiębiorców, organizacji pozarządowych oraz mediów. W efekcie zawiązują się partnerstwa i sieci - formalne i nieformalne powiązania pomiędzy instytucjami publicznymi i niepublicznymi, w ramach których przebiega proces podejmowania decyzji i zarządzania ${ }^{37}$.

$\mathrm{Z}$ drugiej strony, w tego typu partnerstwach wskazuje się często na różne problemy funkcjonowania organizacji zaangażowanych we współpracę. Istnieje tendencja do dominacji sektora publicznego, angażowania podmiotów najbardziej wpływowych i wykluczania najsłabszych przedstawicieli sektora społecznego, instrumentalne wykorzystywanie partnerstw przez najbardziej wpływowych interesariuszy do

35 S. Borkowska, Partnerstwa międzysektorowe według koncepcji naukowych i ram formalno-prawnych, [w:] Układ otwarty. Miejskie partnerstwa międzysektorowe, red. S. Borkowska, E. Zielińska, ResPublica Nova Warszawa 2014, s. 25-26.

36 M. Kaliszewska, Partnerstwo międzysektorowe $w$ ekonomii społecznej - współpraca $z$ administracja publiczna i biznesem, [w:] Partnerstwo - współpraca międzysektorowa $w$ realizacji celów społecznych, red. A. Handzlik, J. Głowacki, Małopolska Szkoła Administracji Publicznej, Uniwersytet Ekonomiczny w Krakowie, Kraków 2012, s. 21.

37 P. John, Local Governance in Western Europe, Sage, London 2001, s. 45. 
pozyskania środków na własne cele czy też znikomą polityczną odpowiedzialność władz partnerstw wobec społeczności lokalnej3.

\section{Partnerstwo lokalne w Polsce - perspektywy i zagrożenia}

Partnerstwo lokalne rozumiane jako specyficzna forma organizowania się w społeczeństwie obywatelskim w Polsce powstało po akcesji do Unii Europejskiej, większość z nich utworzona została z inicjatywy lokalnych władz. Z perspektywy czasu można zauważyć, że zdają się być nadzwyczaj dojrzałymi bytami - mimo całego bagażu niedoskonałości i ułomności (prawnych, finansowych, organizacyjnych, kadrowych). Wytworzyły one w ostatnich latach nową perspektywę rozwoju lokalnego w Polsce, opartą na partycypacji i aktywizacji lokalnej. W tak krótkim czasie organizacje te zbudowały sprawnie działające struktury organizacyjne, cechujące się różnorodnością aktywności, proponujące społecznościom lokalnym bogaty wachlarz oferty edukacyjnej, doradczej i informacyjnej, służących rozwojowi kapitału ludzkiego ${ }^{39}$.

Nie ulega wątpliwości, że partnerstwo lokalne to sprawa o doniosłym znaczeniu dla przyszłości polskiego społeczeństwa. Oznacza wsparcie dla przedsiębiorców, a zatem wzmocnienie pozycji w konkurencyjnych warunkach transformacji ustrojowej i w procesie integracji społecznej z krajami UE. Ponadto idea partnerstwa doskonale wpisuje się w szeroki obszar ekonomii społecznej, której zasady są zgodne z założeniami strategii lizbońskiej, szczególnie ważnymi w obszarach spójności społecznej obejmujących zatrudnienie, walkę z biedą i wykluczeniem społecznym, jak również demokrację uczestniczącą i rozwój. Niezmiernie ważną cechą partnerstw lokalnych jest współpraca partnerów na każdym etapie realizacji określonych działań prorozwojowych i tworzenie systemu trwałych więzi i powiązań pomiędzy poszczególnymi instytucjami ${ }^{40}$.

Dalszy jego rozwój jest bezpośrednio związany z poziomem kapitału społecznego, który buduje się między innymi poprzez kształtowanie wzajemnych relacji pomiędzy instytucjami publicznymi, organizacjami społecznymi oraz instytucjami

38 M. Furmankiewicz, Wspótrządzenie czy ukryta dominacja sektora publicznego? Koncepcja governance w praktyce lokalnych grup działania LEADER, „Studia Regionalne i Lokalne” nr 1(51), 2013, s. 74.

39 Partnerstwa lokalne w Polsce - kondycja, struktura, wyzwania. Raport badawczy, red. A. Jarzębska, Fundacja Partnerstwo dla Środowiska, Kraków-Toruń 2010, s. 65.

40 D. Jegorow, Strategia partnerstwa lokalnego, Wyższa Szkoła Stosunków Międzynarodowych i Komunikacji Społecznej, Chełm 2009, s. 8. 
gospodarczymi. Relacje te powinny mieć charakter partnerski, który należy traktować w kategoriach wartości, zaś trwałe partnerstwo jest podstawą efektywnego rozwoju lokalnego.

Analizując partnerstwo lokalne, należy jednak zauważyć, że jest ono wolne od pewnych wad czy też ograniczeń. Na pierwszym miejscu należy wymienić czasochłonność organizowania i długi okres karencji, czyli oczekiwania na pierwsze jego rezultaty. Problemem jest także potrzeba posiadania silnego lidera, zarówno instytucjonalnego, jak i personalnego. Nie zawsze bowiem osoby zajmujące wysokie stanowiska w organach samorządu terytorialnego posiadają odpowiednie cechy przywódcze, co nie sprzyja pełnemu wykorzystaniu potencjału partnerskich struktur. Ponadto partnerstwo niesie też ryzyko powstania zamkniętej grupy partnerów, którzy zżyci we wzajemnej symbiozie nie dopuszczają do współpracy innych podmiotów. Niebezpieczeństwo stanowi także dążenie do nadmiernego poszerzania zakresu kompetencji partnerstwa. Koordynowanie działań może wtedy przynieść skutki przeciwne do zamierzonych. Zamiast działać jak katalizator rozwoju, partnerstwo wchłania w siebie wszelkie dotychczasowe inicjatywy. W efekcie poza nim tworzy się społeczna pustka ${ }^{41}$.

\section{Podsumowanie}

Poprowadzone rozważania miały na celu określenie partnerstwa lokalnego w ekonomii społecznej rozumianego jako nowy paradygmat budowania spójności społecznej. Postawiona na wstępie teza została poddana krytycznej analizie literatury przedmiotu, z której jednoznacznie wynika, że w rozwoju partnerstw lokalnych ważne jest przede wszystkim zaangażowanie i współdziałanie wszystkich kluczowych partnerów, co z kolei łączy osoby z różnych środowisk społecznych i ekonomicznych w realizacji konkretnej inicjatywy partnerskiej. Niezależnie od formy, partnerstwo stanowi jeden z najistotniejszych czynników decydujących o powstawaniu podmiotów ES jak również powodzeniu podejmowanych przez nie działań ${ }^{42}$.

Co prawda samo pojęcie partnerstwa należy nadal do terminów nieostrych na gruncie norm prawnych, niemniej jednak pojawia się coraz częściej w dokumentach programujących działania administracji publicznej z lokalnym biznesem

41 W. Rudolf, Możliwości wykorzystania koncepcji governance w zarządzaniu publicznym, „Problemy Zarządzania, Finansów i Marketingu" nr 18, 2011, s. 240-241.

42 J. Gądecki, Roczne programy współpracy. Co z nich wynika dla rozwoju ekonomii społecznej w Polsce. Raport podsumowujący badania Barometr Wspótpracy 2007, „Ekonomia Społeczna. Teksty” nr 10, 2007, s. 4. 
i organizacjami pozarządowymi. Praktycznie wszystkie regiony naszego kraju model partnerski wprowadziły lub wprowadzają do swoich strategii z obszaru realizowanej polityki społecznej. Działaniem utrwalającym partnerstwo jest upowszechnianie świadomości i wiedzy o wielostronnych partnerstwach wśród społeczności lokalnej. Stąd też muszą one zyskać poparcie lokalnych władz, pozwalające zaistnieć partnerom jako element społeczności, którą współtworzą, oraz potrzebują wsparcia lokalnych przedsiębiorców, którzy będą upatrywać w przedsiębiorcach społecznych biznesowych partnerów w skali mikro, natomiast w skali makro tzw. rynkowego tworu, współtworzącego lokalną gospodarkę. Dla sukcesu przedsiębiorstwa społecznego konieczna jest społeczna akceptacja, świadomość korzyści wynikających z tworzenia i rozwijania różnych konfiguracji podmiotów rynkowych i społecznych oraz wiedza współmieszkańców-współobywateli, jak funkcjonuje i nośnikiem jakich wartości jest przedsiębiorstwo społeczne. Szansy rozwoju oraz uzasadnienia dla trwania partnerstw w oparciu o budowanie relacji społecznych, na równi z rynkowymi, oraz opartych na budowaniu kapitału społecznego można także upatrywać w środkach unijnych i innych zewnętrznych (nieosiągalnych dla podmiotów urzeczywistniających jedynie cele związane z kumulowaniem zysków) mechanizmach finansowania. To właśnie one mogą wspomagać utrwalenie w polskim prawie dobrych praktyk rynkowych, wnoszących również wartości pozafinansowe, oparte na kapitale społecznym ${ }^{43}$.

Aktualne przepisy unijne zobowiązują do tworzenia partnerstw jako instrumentów ścisłej współpracy pomiędzy poszczególnymi państwami członkowskimi podczas przygotowania, realizacji, monitorowania i oceny programów. Na poziomie krajowym oznacza to włączanie w ten proces partnerów gospodarczych i społecznych z poszanowaniem ich kompetencji i możliwości. Nie ulega wątpliwości, iż dalszy rozwój ekonomii społecznej uzależniony jest przede wszystkim od współpracy i pełnego zaangażowania wszystkich partnerów tego procesu.

\section{Local partnership in social economy as a new paradigm in building of social cohesion}

The social economy has been trying to recognize its partnering role by the public and business sectors over recent years. The results are visible in the increasing use of its instruments in policy implemented by both the government and the regional authorities. The essence of local partnership is one of the key issues

43 A. Waligóra, Uwarunkowania zróżnicowania typów przedsiębiorczości społecznej w Polsce, Uniwersytet Ekonomiczny w Poznaniu, Poznań 2016, s. 125-126. 
inherent in the new paradigm of building social cohesion and is a tool for a new economic and social order. The task of local partnership, understood as a kind of relationship between public entities, business and non-governmental organizations based on the principles of dialogue, reciprocity and equivalence, is to combine knowledge, experience and initiatives of various people and institutions in solving social problems.

Keywords: local partnership, social economy, local self-government

\section{Literatura}

1. Baron-Wieczorek M., Grzanka I., Partnerstwo społeczno-publiczne we wspólnotach terytorialnych, „Zeszyty Naukowe Politechniki Śląskiej” nr 76, 2014.

2. Borkowska S., Partnerstwa międzysektorowe wedlug koncepcji naukowych i ram formalno-prawnych, [w:] Układ otwarty. Miejskie partnerstwa międzysektorowe, red. S. Borkowska, E. Zielińska, ResPublica Nova, Warszawa 2014.

3. Brinkerhoff J.M., Government-Nonprofit partnership: A defining framework, „Public Administration and Development" Vol. 22, 2002.

4. Furmankiewicz M., Wspólpraca międzysektorowa w ramach „partnerstw terytorialnych” na obszarach wiejskich w Polsce, „Studia Regionalne i Lokalne” nr 2(24), 2006.

5. Furmankiewicz M., Wspótrządzenie czy ukryta dominacja sektora publicznego? Koncepcja governance w praktyce lokalnych grup działania LEADER, „Studia Regionalne i Lokalne" nr 1(51), 2013.

6. Gądecki J., Roczne programy wspótpracy. Co z nich wynika dla rozwoju ekonomii społecznej w Polsce. Raport podsumowujący badania Barometr Wspótpracy 2007, „Ekonomia Społeczna. Teksty" nr 10, 2007.

7. Hudson B., Exworthy M., Peckham S., The Integration of Localised and Collaborative Purchasing: a Review of the Literature and Framework for Analysis, Nuffield Institute for Health, University of Leeds, University of Southampton 1998.

8. Jabłońska A., Drażba M., Partnerstwo publiczno-społeczne jako „przystępna” forma partnerstwa międzysektorowego, [w:] Partnerstwo międzysektorowe. Możliwości, zasady, realizacja, red. M. Perkowski, Wydawnictwo Prawo i Partnerstwo, Białystok 2009.

9. Jegorow D., Strategia partnerstwa lokalnego, Wyższa Szkoła Stosunków Międzynarodowych i Komunikacji Społecznej, Chełm 2009.

10. John P., Local Governance in Western Europe, Sage, London 2001.

11. Juros A., Biały A., Partnerstwo w praktyce przedsiębiorstw ekonomii społecznej. Dobre praktyki, Lubelska Spółdzielnia Socjalna Koziołek, Lublin 2011. 
12. Kalisiak-Mędelska M., Partnerstwo lokalne - istota i znaczenie na przykładzie lokalnych grup działania, „Biblioteka Regionalisty” nr 13, 2013.

13. Kaliszewska M., Partnerstwo międzysektorowe w ekonomii społecznej - wspólpraca $z$ administracja publiczna i biznesem, [w:] Partnerstwo - wspótpraca międzysektorowa $w$ realizacji celów społecznych, red. A. Handzlik, J. Głowacki, Małopolska Szkoła Administracji Publicznej, Uniwersytet Ekonomiczny w Krakowie, Kraków 2012.

14. Kotarba B., Zasady partnerstwa $w$ wybranych działaniach samorzadów gminnych, [w:] Partnerstwo w sferze publicznej, red. A. Kołomycew, B. Kotarba, Scholar, Warszawa 2014.

15. Kozłowski T., Partnerskie pryncypia, [w:] Partnerstwo społeczne - model rozwoju Polski, red. W. Misztal, A. Zybała, Centrum Partnerstwa Społecznego DIALOG, Warszawa 2008.

16. Krajowy Program Zabezpieczenie Społeczne i Integracja Społeczna na Lata 2006-2008, MPiPS, Warszawa 2006.

17. Lewandowska M., Droga do partnerstwa - kilka ważnych pytań, FISE, Warszawa 2013.

18. Local Partnership for Rural Development, OECD, Paris 1990.

19. Lukesch R., The LAG - handbook. A guide through the stunning world of local actions groups, LEANDER+ OBSERVATORY CONTACT POINT, Brussels 2007.

20. Partnerstwa lokalne w Polsce - kondycja, struktura, wyzwania. Raport badawczy, red. A. Jarzębska, Fundacja Partnerstwo dla Środowiska, Kraków-Toruń 2010.

21. Projekt „Potencjał - Działanie - Rozwój: nowy wymiar współpracy Miasta Płocka i płockich organizacji pozarządowych", Procedura tworzenie partnerstwa publiczno-społecznego na prowadzenie Centrum Organizacji Pozarzadowych i Inicjatyw Obywatelskich Gmina - Miasto Płock, Płock 2014.

22. Przez współpracę do sukcesu. Partnerstwo lokalne na rynku pracy, red. A. Sobolewski, MPiPS, Warszawa 2007.

23. Roffiaen Ch., Rethinking the principle of subsidiarity, „Brussels Report” 2003.

24. Rudolf W., Możliwości wykorzystania koncepcji governance w zarządzaniu publicznym, „Problemy Zarządzania, Finansów i Marketingu” nr 18, 2011.

25. Ruszewski J., Współpraca sektora administracji publicznej i sektora ekonomii społecznej, [w:] Ekonomia społeczna $w$ teorii i praktyce, red. A. Grzybowska, J. Ruszewski, Centrum Aktywności Społecznej PRYZMAT, Suwałki 2010.

26. Schimanek T., E jak EQUAL. P jak Partnerstwo, Instytut Spraw Publicznych, Warszawa 2007.

27. Tkaczuk M., Partnerstwo publiczno-społeczne jako etap ewolucji podmiotów polityki społecznej w Polsce, „Annales Universitatis Mariae Curie-Skłodowska”, Sectio H Oeconomia 42, 2008.

28. Tennyson R., Wilde L., The guiding hand. Brokering partnerships for sutainable development, United Nations Department of Public Information, New York 2000. 
29. Waligóra A., Uwarunkowania zróżnicowania typów przedsiębiorczości społecznej w Polsce, Uniwersytet Ekonomiczny w Poznaniu, Poznań 2016.

30. Wejcman Z., Dialog i partnerstwo a ekonomia społeczna, „Ekonomia Społeczna. Teksty" nr 9, 2007.

31. Woźniczka J., Partnerstwo jako narzędzie społecznej odpowiedzialności biznesu, http://odpowiedzialnybiznes.pl/artykuly/partnerstwo-jako-narzadzie-spolecznej odpowiedzialnosci-biznesu

32. Wygnański J., Skuteczne animowanie kultury współpracy, [w:] Partnerstwo - współpraca międzysektorowa w realizacji celów społecznych, red. A. Handzlik, K. Głowacki, Małopolska Szkoła Administracji Publicznej, Uniwersytet Ekonomiczny w Krakowie, Kraków 2012.

33. Wygnański J., Skuteczne animowanie kultury wspótpracy - czynniki sukcesu w procesie budowy partnerstw, [w:] Partnerstwo - współpraca międzysektorowa $w$ realizacji celów społecznych, red. A. Handzlik J. Głowacki, Małopolska Szkoła Administracji Publicznej, Uniwersytet Ekonomiczny w Krakowie, Kraków 2014.

34. Ustawa z dnia 24 kwietnia 2003 r. o działalności pożytku publicznego i wolontariacie, DzU nr 96, poz. 873 z późn. zm.

35. http://wiadomosci.ox.pl/wiadomosc,25024, partnerstwo-na-rzecz-ekonomii-.html

36. http://www.portalsamorzadowy.pl/polityka-i-spoleczenstwo/cenne-partnerstwo-takze-spoleczno-prywatne,20950.html 